\title{
ANALISIS PERANCANGAN SI-STOK UNTUK MENGURANGI BULLWHIP EFFECT DALAM INDUSTRI GARMEN
}

\author{
Ifan Setyowinarno ${ }^{1}$, Jeffri Dian Asmoro' ${ }^{2}$ Yusuf Amrozi ${ }^{3}$ \\ 1,2,3 Fakultas Sains dan Teknologi, \\ Universitas Islam Negeri Sunan Ampel.
}

ifanwinarno90@gmail.com, jeffridianasmoro@gmail.com, yusufamrozi@uinsby.ac.id

\begin{abstract}
The garment industry has a large contribution to Indonesia's exports. Currently, this industry is facing various challenges, including changes in market demand that are getting faster along with the acceleration of the development of world fashion which does not only rely on the seasons but fashion trends, causing orders for apparel to change rapidly causing the high demand for raw materials from each industrial component to become unstable. stable. The obstacle that is often encountered in the implementation of supply chain management is the lack of coordination, causing distortion of information which results in a bullwhip effect. This research uses the literature study method for data collection and the waterfall method for system design. The final result of this research is a stock information system which is expected to reduce distortion of information and clarify coordination between components in a garment industry so as to reduce the bullwhip effect and stabilize demand for raw materials from each industrial component.
\end{abstract}

Keywords: Bullwhip Effect, inventori, Industri Garmen

\section{PENDAHULUAN}

Dalam suatu perusahaan proses pengadaan bahan baku dari supplier merupakan ujung tombak dari sebuah keberhasila perusahaan tersebut. Dalam menangani hal ini, perusahaan memerlukan adanya suatu cara untuk mempermudah proses tersebut yakni dengan bantuan Supplay Chain Management (SCM). SCM merupakan jaringan perusahaan-perusahaan yang melakukan kerjasama untuk menciptakan sebuah keuntungan yang dapat memberi kesuksesan pada perusahaan dan konsumen. SCM merupakan integrasi beberapa kunci proses bisnis yang akan menjalankan barang dan jasa kepada pelanggan. Salah satu factor keberhasilan untuk penerapan SCM adalah internet. Dengan adanya internet ini pihak-pihak yang bersangkutan akan mendapatkan dan membagian informasi dengan cepat, mudah dan akurat. Informasi merupakan kunci utama dari SCM. Putusnya informasi akan mengurangi kinerja dalam proses SCM dalam suatu industri, Seperti halnya dalam industri garmen. Suatu konveksi akan memerlukan waktu lama dalam memulai proses pengerjaan mengingat biasanya pemesanan dilakukan secara batch yang pada akhirnya berimbas pada persediaan aktual berbeda dengan estimasi permintaan yang pada akhirnya timbul bullwhip effect. Oleh karena itu perlu adanya sistem informasi yang mengatur dari hilir ke hulu (bottom up) yang dapat mengurangi dampak meningkatnya permintaan dari retailer. Adapun beberapa masalah yang sering terjadi dalam pengadaan barang yaitu terlambatnya pengadaan barang baku yang akan di terima oleh perusahaan. Hal seperti ini terjadi karena adanya penyebab timbulnya bullwhip effect, antara lain : (1) Demand Forecasting yaitu Peramalan Permintaan.; (2) Lead Time yaitu tenggang waktu antara pemesanan dan barang datang.; (3) Batch Ordering ialah terjadinya penumpukan barang order.; (4) Fluktuasi Harga yaitu pemesanan barang yang meningkat karena barang harganya menurun drastis.; (5) Perubahan Pemesanan. Berdasarkan permasalahan diatas, maka penulisan ini bertujuan untuk: (1) mengidentifikasi proses bisnis serta menganalisa suatu permasalahan yang terjadi dan dapat menimbulkan bullwhip effect.; (2) mengatasi pengurangan bullwhip effect dengan menggunakan perancangan sistem informasi. 


\section{KAJIAN LITERATUR Supply Chain Management}

Menurut Indrajit dan Djokopranoto [1] supply chain adalah:"suatu tempat organisasi menyalurkan barang produksi dan jasanya kepada para pelanggannya". Lee dan Whang [2] mendefinisikan supply chain management adalah: "Suatu sistem jaringan yang terdiri atas beberapa perusahaan yang memiliki tujuan sama sebagai tempat organisasi menjalankan barang dan jasa kepada pelanggan".

Komponen Supply Chain Management menurut Turban [3] terdiri dari tiga komponen utama yaitu : (1) Rantai Suplai Hulu/Upstream Supply Chain Segment, meliputi aktivitas perusahaan manu-facturing dengan para supplier dan koneksinya (para penyalur secondtier). (2) Manajemen Internal Suplai Rantai/Internal Supply Chain Segment, meliputi semua proses inhouse yang digunakan dalam mentransformasikan input dari supplier ke dalam keluaran organisasi itu.; (3) Segmen Rantai Suplai Hilir/Downstream Supply Chain Segment meliputi aktivitas yang melibatkan pengiriman produk kepada pelanggan akhir.

\section{Sistem Informasi}

Menurut Laudon (2012:16) sistem informasi adalah komponen-komponen yang saling berkaitan yang bekerja bersama-sama untuk mengumpulkan, mengolah, menyimpan, dan menampilkan informasi untuk mendukung pengambilan keputusan, koordinasi, pengaturan, analisa, dan visualisasi pada sebuah organisasi. Menurut Whitten, Bentley, dan Ditman (2009:10) sistem informasi adalah pengaturan orang, data, proses, dan informasi (TI) atau teknologi informasi yang berinteraksi untuk mengumpulkan, memproses, menyimpan, dan menyediakan sebagai output informasi yang diperlukan untuk mendukung sebuah intansi atau organisasi.

Menurut O'Brien (2010:34) mengatakan bahwa komponen Sistem Informasi terbagi atas beberapa hal, yaitu:

a) Sumber daya data (sebagai data dan pengetahuan).

b) Sumber daya Manusia (sebagai pemakai akhir dan ahli SI).

c) Sumber daya software (sebagai program dan prosedur). d) Sumber daya hardware (mesin dan media).

e) Sumber daya jaringan (sebagai media komunikasi dan dukungan jaringan).

Bedasarkan dari pernyataan di atas, maka dapat disimpulkan bahwa Sistem informasi merupakan suatu sistem yang mempunyai kemampuan untuk mengumpulkan informasi dari semua sumber dan menggunakan berbagai media untuk menampilkan informasi.

\section{Bullwhip Effect}

Definisi Bullwhip effect menurut Christer Carlsson dan Robert Fuller (2001) adalah "Suatu fenomena dimana permintaan kepada supplier memiliki variansi yang besar daripada penjualan yang dilakukan kepada buyer dan terjadi distorsi kepada level suppy chain yang lebih tinggi." Sedangkan Bullwhip effect menurut Davids Simchi-levi, Dkk, 2000, dalam buku Designing and managing the supply chain, adalah sebagai berikut: "Peningkatan variability dari level bawah menuju level atas dan dalam suatu network supply chain."

Bullwhip effect adalah salah satu dari penyebab penting bagi efesiensi dalam sistem manajemen rantai pasokan. Sejak Forrester terkena sekitar 45 tahun yang lalu bahwa perbedaan permintaan menaikkan rantai pasokan dari konsumen untuk pedagang, para peneliti tampaknya untuk alasan dan berusaha untuk menemukan penanggulangan.(Kumar M. , 2016). Pasar cenderung lebih dan lebih berorientasi pelanggan, yang ketidakpastian terhubung dengan permintaan pelanggan akhir dan yang konsekuensi dalam rantai pasokan telah menjadi penting dalam subjek penelitian. Bullwhip effect di sebabkan oleh ketidakpastian, dan beberapa peneliti telah mengidentifikasi penyebab untuk efek ini dan telah mencoba untuk mengusulkan metode untuk menguranginya (Kumar \& Khola, 2016).

\section{Industri Garmen}

Garmen merupakan sebuah bisnis usaha yang bergerak di bidang pembuatan pakaian atau tekstil yang dikelola dengan sistem menejemen dan juga sistem administrasi yang lebih baik di bandingkan dengan konveksi. Ya, garmen ini merupakan sebuah pabrik pakaian atau tekstil yang memproduksi berbagai macam dan jenis pakaian untuk diperjual belikan kembali sehingga karyawan yang bekerja pada 
garment ini terbilang sangat banyak. Dan untuk proses pengerjaan pembuatan pakaian atau tekstil pada garmen ini terbilang sangat cepat dan juga rapi serta di dukung oleh beberapa mesin jahit yang sangat modern. Industri garment adalah industri yang memproduksi pakaian jadi dan perlengkapan pakaian. Yang dimaksud dengan pakaian jadi adalah segala macam pakaian dari bahan tekstil untuk laki-laki, wanita, anak-anak dan bayi. Bahan bakunya adalah kain tenun atau kain rajutan dan produknya antara lain berupa kemeja (shirts), blus (blouses), rok (skirts), kaus (t-shirts, polo shirt, sport swear), pakaian dalam (underwear) dan lain-lain. Industri tersebut merupakan penyumbang devisa terbesar bagi negara setelah minyak dan gas bumi (Migas). Di pasar internasionals endiri, produk garment Indonesia telah memiliki posisi yang cukup bagus, dengan pangsa antara $3 \%$ sampai $4 \%$ dari total nilai ekpsor dunia.

\section{METODE PENELITIAN Alur Kerangka Penelitian}

Dalam rangka mengembangkan layanan Sistem Informasi untuk mengurangi Bullwhip Effect dibutuhkan tahapan pengerjaan yang mengacu pada struktur dasar dari metode Waterfall. Tahapan tersebut dapat dijelaskan pada gambar 1 dibawah ini:

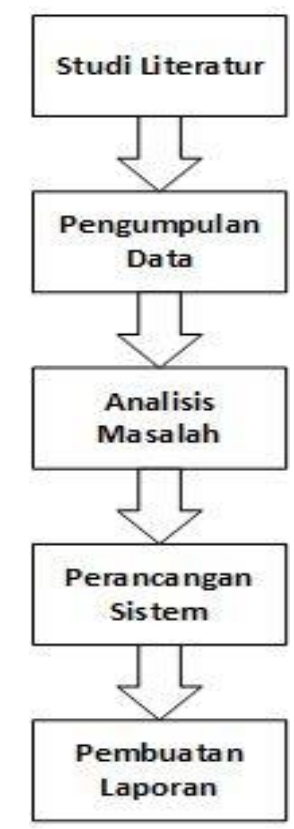

Gambar 1 Alur Penelitian

\subsection{Studi Literatur}

Kegiatan ini meliputi studi pustaka berupa pengayaan materi tentang rancang bangun perusahaan dan studi kasus rancang bangun perusahaan yang telah dilakukan orang lain sebelumnya.

\section{Perancangan Sistem}

Kegiatan ini meliputi pendefinisian seluruh sistem yang terlibat pada rancang bangun tersebut. Perancangan Arsitektur dan proses bisnis sudah termasuk dalam perancangan sistem.

\section{HASIL DAN PEMBAHASAN}

Pada pembahan ini langsung memaparkan hasil dari perancangan tampilan. Perancangan tampilan adalah sebuah tahap untuk menampilkan tampilan sistem sesungguhnya yang sudah dirancang dan dibuat dalam bentuk yang nyata, pada tahap ini tampilan sistem sudah dalam bentuk online dan terhubung dengan database sistem. Berikut adalah tampilan nyata sistem informasi stok barang industri garmen:

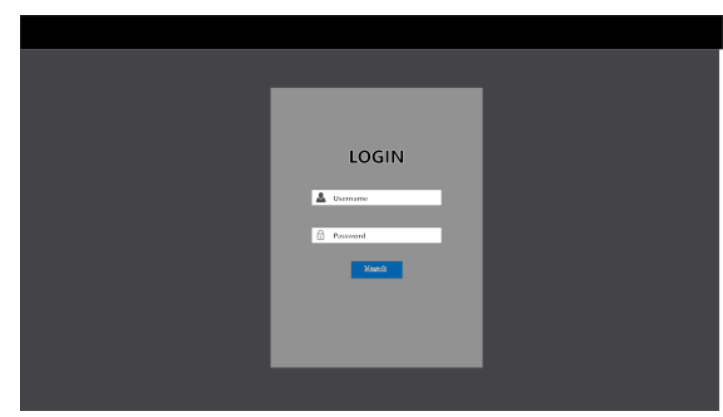

Gambar 2 Halaman Login

Tampilan login adalah tampilan awal sebelum memasuki halaman utama dalam sistem. Dalam hal ini administrator harus memasukan username dan password sesuai dengan database yang telah disiapakan. 


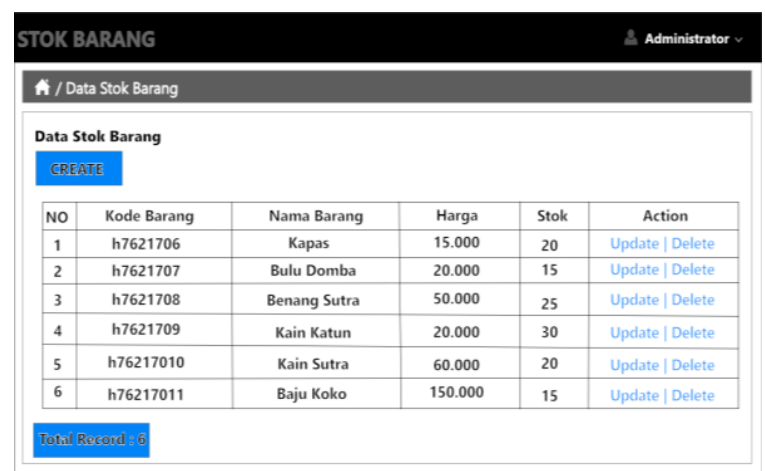

Gambar 3 Tampilan data stok barang

Data stok barang menjelaskan jumlah barang yang tersedia dalam gudang penyimpanan setiap komponen industri garmen. Dengan disajikannya data dalam bentuk tabel agar mudah dipahami. Administrator dapat mengupdate kapanpun sesuai dengan laporan dari setiap gudang.

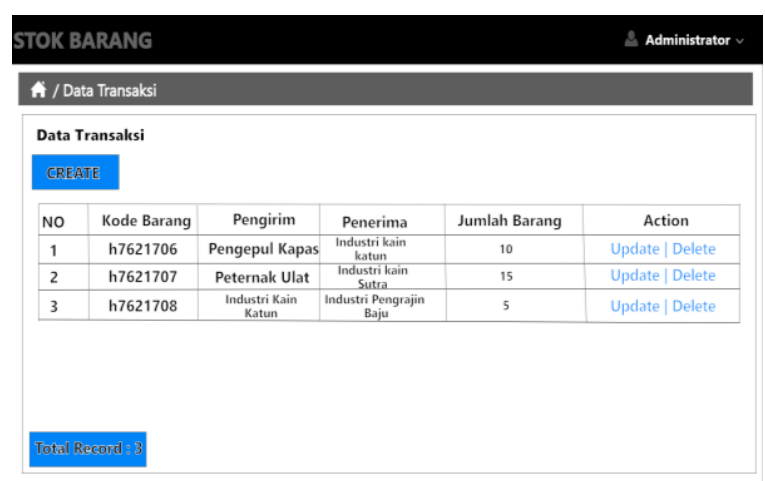

Gambar 4 Tampilan Data Transaksi

Data Transaksi adalah data yang menjelaskan transaksi yang dilakukan dari setiap komponen industri garmen yang terhubung. Data traksaksi dapat membantu mempermudah dan memperjelas alur transaksi yang telah dilakukan. Dengan ini akan memperkecil kemungkinan distorsi informasi dari hulu ke hilir dalam sistem manajemen rantai pasok yang diterapkan.

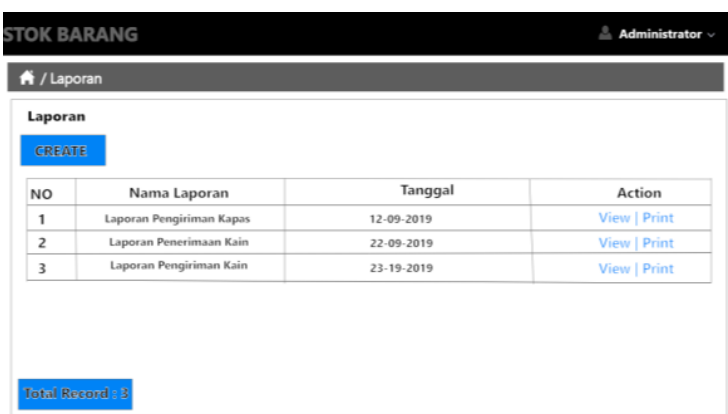

Gambar 5. Tampilan Laporan

Menu Laporan dalam sistem akan menunjukan bukti riil dari setiap proses transaki yang dilakukan. Hal ini akan memperkuat keakuratan proses bisnis dan memperkecil kemungkinan manipulasi data oleh pihak lain. Data yang disajikan memiliki format exel yang akan mempermudah dalam proses perhitungan dalam proses binis.

\section{KESIMPULAN}

- Bullwhip dapat terjadi karena kurangnya koordinasi yang jelas dari komponen yang terhubung dalam proses manajemen rantai pasok yang diterapkan dalam industri garmen. Hal ini dapat dikurangi dengan pemanfaatan sistem informasi stok barang yang akan memperjelas alur transaksi yang dilakukan oleh setiap komponen industri yang terhubung.

- Sistem informasi stok barang adalah sistem informasi yang menjelaskan alur dari proses transaksi dalam industri garmen yang saling terhubung. Sistem ini dirancang untuk memaparkan data stok barang dari setiap gudang, alur transaksi dari setiap komponen industri, dan laporan pengiriman dan penerimaan barang.

- Dalam penerapannya sistem ini hanya dapat berjalan dengan maksimal apabila pihak industri garmen telah menerapkan manajemen rantai pasok dan memiliki kerjasama yang jelas dengan industri lain yang saling terhubung.

\section{DAFTAR PUSTAKA}

[1]. Andita, A., \& Jaya, T. I. (2018). Rancang Bangun Sistem Informasi Manajemen Rantai Pasokan Di Pt Argo Pantes. Jurnal Teknik Informatika, 9(2), 158-165. https://doi.org/10.15408/jti.v9i2.5607

[2]. Bayu, C., Susilo, R., \& Kristyanto, B. (1998). Analisa bullwhip effect dengan metode periodic review. (44), 
$159-166$.

[3]. Effect, B., \& Supply, P. (2008). ANALISA BULLWHIP EFFECT PADA SUPPLY CHAIN ( STUDI KASUS PADA PT . ISTANA CIPTA SEMBADA SIDOARJO) Tri Susilo Teknik Industri FTI - UPN " Veteran "Jawa Timur. 64-73.

[4]. Gumelar, A. S., Saputra, M. C., \& Wardani, N. H. (2017). Analisa Kebutuhan dan Perancangan Sistem Informasi Produksi Dinas Peternakan dan Kesehatan Hewan Kabupaten Malang Berbasis Teknologi Service Oriented Architecture. Jurnal Pengembangan Teknologi Informasi Dan Ilmu Komputer (J-PTIIK) Universitas Brawijaya, 1(11).
[5]. Kartu, K., Majalah, L., Bilah, M., \& Cuplikan, S. (2016). Teknologi Informasi Lanjutan. 90.

[6]. Yogantara, H. (2016). Pembangunan Sistem Informasi Supply Chain Management (SCM) DI CV. SKYLAR. (112).

[7]. Zaroni. (2015). Mengelola Bullwhip Effect. 40194. Retrieved from http://supplychainindonesia.com/new/wpcontent/files/Mengelola_Bullwhip_Effect.pdf 